\title{
Trends in the Development of Legislation on Innovation Procurement
}

\author{
Anastasia Astashkevich \\ PhD candidate at Business and Corporate Law Department, FBGOU VPO "Moscow State University of \\ Law named after O.E.Kutafin (MSAL)", 123995, Moscow, Sadovaya-Kudrinskaya street, build.9

\section{Lyubov Andreeva}

Prof. Dr., Professor at Business and Corporate Law Department, FBGOU VPO "Moscow State University of Law named after O.E.Kutafin (MSAL)", 123995, Moscow, Sadovaya-Kudrinskaya street, build.9

\section{Doi:10.5901/mjss.2015.v6n5p391}

\begin{abstract}
In the present article the mechanism of legal support of public procurement of goods and services related to the innovation sphere in the Russian Federation has been revealed. Considering the regulations governing relations in this sphere of activity, the author evaluates the effectiveness of the federal contract system formed on the basis of these regulations. Analyzing the advantages and disadvantages of the legal framework of using the state order institution in modern Russia and in a number of foreign countries, the author proves the proposals to improve the system of public procurement in order to stimulate innovation at the most rational use of budgetary funds and prevent corruption. Particular attention is paid to the study of the quality of legal provisions of the Federal Law of 05.04.2013 No. 44-FZ and to justifying the need for further improvement of the federal contract system. In order to conduct this study, the author has widely used scientific publications and statistical data from the official EU websites and state authorities of the Russian Federation.
\end{abstract}

Keywords: public procurement, innovative products, innovations, innovation criteria.

\section{Introduction}

The modern period of development of the Russian economy, accompanied by a significant decrease in energy prices, the introduction of serious economic sanctions against Russia from a number of countries, more than ever sets the country's leadership the task of modernizing the country's economy and its transition into the innovative way of development. Solving this problem is impossible without the use of legal means allowing to draw legislative framework of the economy modernization, the organizational and institutional modernization mechanism that requires the conduct of innovative activities which, in turn, require large-scale financing with the involvement of public funds.

Currently many countries are searching for legal methods of regulation in the innovation sphere, and Russia is not an exception. In the scientific legal environment there is an extensive discussion on the issue of public procurement and on the need for appropriate changes in the Russian legislation related to innovation.

The study of a considerable number of researchers' works shows that science has not developed a unique approach to public procurement in the innovation sphere, objective innovation criteria have not been determined yet.

The aim of the present study is to evaluate, on the basis of the studied legal acts, the practice of regulating public procurement of innovative products in Russia and abroad, the effectiveness of the public procurement system in the Russian Federation, to identify the gaps of legal regulation and develop proposals for its improvement.

Research methodology: Considering the fact that the institution of the state contract contains both public-law and civil-law components, research methods used in the present article shall specify the properties of the mixed legal relation of purely legal value, and its functional potential (as legal means) and substantial (structural) meaning. Accordingly, for a qualitative research methodology of research of the state contract institution shall contain, in addition to civil law methods, methods of administrative and constitutional law and other methods typical for the state and legal science. Therefore the author decided to use the research methods inherent in the mentioned science and theories, namely systemic, historical, dialectical, formal-legal, comparative jurisprudence methods.

This particular combination of divergent methodological techniques and methods should provide not only theoretical but also applied research results, as well as make evidence-based conclusions and noteworthy suggestions for improving the current regulation. 
Results. One of the most important tools to stimulate innovation activity, as a tool of economic policy of modern Russia, is the institution of public procurement. In particular, this is mentioned in the Strategy of innovative development of the Russian Federation in the period up to 2020. The document states that "... in the world practice of public procurement acts as an important resource for creating demand for innovation" (The strategy of innovative development of the Russian Federation, 2011). The foregoing is consistent with the New European Directive on Public Procurement as of 15.01.2014, in which innovations are regarded as one of the strategic drivers of economic growth (DIRECTIVE 2014/24/EU 2014). According to the existing data, in the USA the state order for innovative products under the federal contract system has been successfully used for a long time as a tool of industrial, socio-economic, scientific, technological and innovation policy of the American government. The economic system along with state policies creates a favorable environment for the development of innovative trends in business, legal mechanisms for the transition of innovations from the defense sector to the civilian one. So the public demand for innovation is becoming a key factor in the development and diffusion of new technologies throughout the whole economic sector, contributing to the emergence of new industries (Wessner, C., 2004).

Currently the problem of using the mechanism of public procurement to stimulate innovative development of the Russian economy has become rather pressing. Improving the efficiency of procurement and their impact on innovation activity is based on two principles:

- $\quad$ public procurement system acts as a mechanism of direct budget financing of innovation developments. It is important to improve the validity of planning of volume and range of public procurement, to ensure their interaction with the programs of innovative development of the country and regions;

- public procurement system acts as a tool for regulation and stimulation of innovation through the development of the market of innovative products, including by stimulating demand in the market through the procurement of new products and technologies. In this case, it is important to decrease barriers and create competitive advantages for entering the national market of enterprises producing innovative products (Smotritskaya, I.I., 2010).

The receipt of the state order is a sufficiently reliable way of the interaction between the funds allocated by the state for innovative goals, and the enterprise budget. This particular scheme of distribution of funds has been offered by the state, simplifying the process of public procurement, for the active involvement of a larger number of enterprises in innovative activities and the impact of public management by investing public funds in the Russian economy.

The state order aimed at meeting the government needs, forms the new factors and conditions for the reproduction process, encourages and creates conditions of transition to the innovative type of development. State procurement system can perform an important stimulating function in the formation of the innovative economy, which is to stimulate demand for innovative products, manage innovation processes, create realistic preconditions for activation of innovation activity in the Russian regions.

The reform of the public procurement system implemented since 2006 in Russia, according to its methodology, is largely fragmented and procedural in nature, that does not allow to drastically improve the situation in meeting the needs of the state (public) sector. In this case, the total amount of the budget funds spent on procurement of goods, works and services by government authorities at various levels in 2013, amounted to more than 8.5 trillion rubles, the volume of procurement made by state-owned companies, unitary enterprises, budgetary and autonomous institutions, amounted to more than 9 trillion rubles. That is, about 25\% of the country's GDP is redistributed through the contract system in the market of public procurement and procurement of the corporate sector (http//zakupki.gov.ru).

Since January 1, 2014 a new phase of the reform began - the Federal Law as of April 5, 2013 No. 44-FZ "On the contract system in the procurement of goods, works and services for state and municipal needs" (further - the Law on CS) came into force. The purpose of establishing the contract system is to improve the effectiveness of the provision of public needs through the implementation of a systematic approach to the formation, conclusion and execution of state and municipal contracts, transparency of the entire procurement cycle from planning to acceptance and evaluation of results.

Since 2014 the development of the state contract system and the state order on innovation within the framework of this system occurs in line with the legal provisions of the new Law on CS. The analysis of the norms of this law allows to speak about its progressiveness, orientation to the development of civilized contractual relationships, creation of more favorable conditions (unlike the current ones) for the development of the state order for innovation (Smotritskaya, I.I., Chernykh, S.I., 2012).

In economically developed countries, government contracts from various government organizations concluded to conduct research and development and production of innovative products are ones of the most important tools to support innovative small and medium-sized enterprises. Such contracts require careful coordination of all the main characteristics 
of innovative projects, expected results, terms of the contracts and necessary costs. Typically, the amount of estimated costs is fixed before the start of works, and the final payment is made after their completion. Grants and subsidies are usually provided to support radical and risky projects implemented by innovative small businesses. Government contracts should necessarily comply with the following key requirements:

- the Contractor shall receive the necessary results of the scientific and technical problem stated by the Customer, within a certain term of the contract;

- the Customer shall provide loans necessary to the Contractor for the entire period of works execution;

- the Customer shall provide guarantees for the purchase of future results of the works executed by the Contractor (Afonasova, M.A., 2013)

Observers note that currently certain countries, EU members, provide the state assistance for conducting research in the form of grants. The rationale for the allocation of such grants is usually "the need for assistance, or to create an incentive effect, or motivate the company to conduct research, which would not have been conducted under other circumstances " (Nikonova, 2013).

Historically, certain types of state assistance have not been used any more, other types continue to be provided, while some types of the state assistance (and its scope) are subject to a more detailed and careful monitoring by the EU authorities. Thus, countries, EU members, are increasingly stimulating private companies to conduct research by socalled "horizontal" rules legalized within the EU. They include assistance in the following areas:

- climate change and environmental protection;

- research, development and innovation;

- restructuring companies appeared in financial hardship;

- assistance to small and medium-sized enterprises;

- measures to combat unemployment;

○ training employees;

○ on risky investments;

- on services of general economic interest (Prange, 2008).

It is clear that in order to obtain approval of the EU Commission on provision of the state assistance in any of these areas, it will also be required to present evidence determined by the Commission in "framework regulations", "manuals" and "general exclusive explanation". And this increases opportunities rather limited by contracts and EU directives. There are threshold values below which assistance can be provided without any consultation with Brussels ("minimal assistance" includes up to 200 thousand Euro during three years). But the matrix of the incompatibility of directions or objectives of the assistance has been created, and it allows to control and punish in cases of circumvention of the main provisions of the EU or in case when a market participant got assistance through different channels.

Anticipating the economic crisis, the EU Commission has approved a special action plan for state assistance, under which the European Commission has adopted EC Guidance as of August 6, 2008 on the basic blocking exclusions. There are other directive objectives, common to the Commission, and methods for their achievement, that are the same for all participants. For example, to encourage R\&D the Lisbon investment strategy was adopted, according to which 3\% of the budget should be sent to member countries for R\&D (it was adopted on the basis of a comparison with the amount of budget allocations for R\&D in the United States and Japan). In this case, it is determined that placement of projects "by transparent and open pricing procedures" is equated to public procurement and not regarded as the state assistance (Prange, 2008).

The opportunities to support R\&D and energy efficiency of small and medium-sized enterprises have been determined by special regulatory measures. A number of areas, including the energy sector, are determined in separate programs, and their financing is equally effected by European Union, individual European Communities (and agencies), the member states and regions. It had been expected that in this case these programs would be attractive for private companies, acting not only as performers (recipients of funds), but also as participants in their financing for future profit (public private partnership). For example, the program "Europe is a smart energy" provides for the issuance of EU grants for the development in one of three areas:

- effective energy and rational use of energy sources;

- renewable energy sources and support of energy diversification;

- effective energy and renewable energy sources for transport (there are also other programs).

These programs are designed in order to involve energy consumers in participation in these programs, while producers have little interest herein.

Finally, in order to directly stimulate R\&D and innovation, on the request of the European Commission, the analysis of the opportunities provided by new directives on public procurement adopted in 2014, has been carried out. 
The main conclusions of the study are as follows: business responds by innovative solutions to market demands, while research investment of the private sector follows the changing needs of customers. The market, as a rule, cannot predict the direction of innovation, and public procurement can cause the demand for innovative solutions. However, to do this it is necessary to allow the developer of such a solution to use intellectual property rights and implement these rights in his/her sole discretion.

In EU states, namely, the public sector generates a significant proportion of demand for innovative products and acts as a key customer and consumer of innovations in areas such as health care service, construction, defense and security, monitoring, control and mitigation of climate change, energy and energy efficiency, transport (Smotritskaya, 2014).

"The guidelines for innovative solutions in the public procurement - 10 examples of good practice" have been prepared on the basis of studies, offering "standard" solutions when placing various types of public procurement (Peca, V., 2012). It was noted that the following provisions should be adopted as the basic ones:

- Pre-Commercial Procurement (PCP) - R\&D procurement at the stage prior to getting the product to the market. PCP includes the orders for the execution of applied research and development, the development of (technological) solutions, prototype development, and development of a limited batch of samples of products (services). Such orders are also generally used to fund research and development required for the specific state (public) needs. Thus, as a rule, the customer simultaneously funds several projects that provide alternative solutions to one problem until he/she can see the benefits of a single project (scientific approach, technological solutions) and refuse to fund the other. As a rule, PCP assumes full public funding.

- Public Procurement of Innovative Solutions (PPI), when the state customer of any level should order the goods for his/her own needs or the needs of the population by innovation criteria, at least, showing preference for "innovative" solutions in the offers of the participants in the assessment.

Here the EU Commission points out that the directives of 2014 regulate R\&D procurement of services, but not works in the scientific field. Thus, it is considered that they do not fall under the concept of the state assistance.

The possibility of contractors (candidates) to offer "options", i.e. alternative solutions in their claims is also provided by directives of 2014. The development and introduction of STEPINZ standards system into the practice of public procurement of the European community have made a major contribution to the development of this provision. This system requires that suppliers enclose innovative business solutions to their applications.

Unfortunately, it must be noted that this practice is incompatible with the current Russian Law No. 44-FZ on the state order placement. According to article 43 of the Law on CS, the participant of the competition or the auction has the right to amend the application just before the deadline for submission of applications. It is absolutely clear that the customer is unable to foresee or describe innovative solutions in advance, before the execution, and sometimes before he/she gets the final result.

Providing freedom of fair competition is a basis of state building and the US legislation. Accordingly, laws and rules governing the organization and conducting public procurement are primarily aimed at ensuring equal rights for all tenderers and at protection against monopolization of the market.

Public procurement system in the United States includes more than four thousand laws, regulations and internal departmental regulations. More consistently, the procedural and "contract" aspects are reflected in the Rules of procurement for federal needs (The Rules). We can briefly characterize this set of regulations as the rules of conclusion of contracts of delivery and services provision by the U.S. Federal government agencies.

In addition to the Rules, placement of the state order is regulated by other acts, such as "Competitiveness at contracting", "On timely payment", "Against failure", etc. Thus, "private" acts are accepted in order to achieve long-term or ongoing political goals, also determining the size and rules of budget funds spending.

The general rule is the placement of a public contract without providing any benefits to individual tenderers. However, historically, the U.S. law provided certain benefits and fixed quotas for some activities for different population groups, so-called "deviations". In addition, incentives - "motives" have been provided where it was appropriate. They are used to support innovative solutions (Appelt, S., 2013).

Another fundamental peculiarity of the American practice is transferring most of the estimated parameters in a cash equivalent. Of course, this difference is more leveled in recent years.

Nevertheless, the chapter "R\&D procurement" of the Rules proposes placement of state contracts on R\&D for the needs of the state customer (or society in the field governed by the state customer - the Federal Agency), so that to create the most favorable conditions for the participation of the best-trained developers, so that they could show maximum flexibility and do not fall under bureaucratic pressure. The Rules provide for two types of order placement: conclusion of the contract (in the case of transfer of R\&D results directly to the state customer) or grants provision (for 
cases where the task of order is to stimulate the directions for the development or implementation of preliminary studies).

American legislator is aware of the problems of procurement of innovative products. Therefore, such form of description of technical specifications of the procurement subject as "an indication of the order" is provided in the current edition of the Rules. It is used in cases where the state customer finds it necessary to leave the tenderer maximum freedom of choice for innovative solutions to achieve the purpose specified in the invitation. And this is despite the fact that the United States is one of the few countries where there is a direct form of a two-step competition during public procurement (Rubvalter, D.A., 2008).

The feature of legislative regulation of public procurement in the U.S. in the field of innovation is that scientific and technological achievements obtained in the process of execution of Federal contracts, will ultimately become the property of the American economy. In addition, the Rules provide "promotion execution", tax procedure incentives, which allow to increase profit margin by improving the characteristics of the product. Contract law of public procurement in the US foresees the state customer's control over the rate of profit in performance of a government contract that is one of the selection criteria (Williamson, O.E., 2002).

As for the programs, as it has already been mentioned, they can be long-term or short-term. Thus, the programs may be of an inter-ministerial and inter-regional nature, i.e. to obtain financing and to focus on solution of the problems of concerned territories and authorities. The specifics of the state support of innovations in the United States are "laws, programs and plans" in strategic areas of science, technology and scientific and technical programs. Such "legislative programs" are of multi-year nature and there are about three thousand of them, including the regional programs.

\section{Discussion}

Unfortunately, in our country the state order has not yet become an effective tool of the implementation of state scientifictechnology and innovation policy and an increase in the innovative activity in the Russian regions. The existing procedure of placement of public procurement is not consistent with fundamental principles of procurement, it does not take into account the peculiarities of innovative products as the subject of the order and is not conducive to effective public procurement from qualified contractors who can offer the best results at an affordable price.

The Law on CS, a primary Russian legislation act on public procurement, is largely of a framework nature, it creates necessary but not sufficient conditions for the development of relevant processes, as practical implementation of key regulations affecting the promotion of procurement of innovative products depends on the timeliness and quality of the development of appropriate regulations acts. First of all, it concerns the establishment of the level of significance for assessing criteria of competitive applications, qualification requirements for participants of the competition with limited participation, opportunities and conditions of concluding a contract of life cycle, the possibility and rules of using the estimated price or a pricing formula of the contract.

The researchers of the Law on CS also indicate that it is largely declarative in nature, since the use of criterion of quality, functional and environmental characteristics of the order object in the evaluation and comparison of bids is not mandatory for the customer, the liability of the customer for the purchase of obsolete, expensive, environmentally harmful and other products is not provided. Creation of lists of innovative products and technologies, recommended for purchase, and outdated, wasteful, environmentally harmful, etc. products and technologies, prohibited from purchase, provided for by "Innovative Russia, 2020", has not also been found in the Law.

It is noted that the regulation of the qualifications and reputation of experts (expert organizations), the criteria and procedures for their selection, procedures of expert evaluation of the tender documents, qualification of bidders and competitive applications and their use by the customer need modifications. In some cases (expensive, technically challenging, innovative orders) the obligation of the customer on the organization of expert examination of the tender documents, qualification of bidders, bids and results of the execution of the contract shall be provided, but not the right for it. The distribution of the relevant rules on procedure of the request for proposals is also advisable.

A sufficiently flexible approach to determining the significance level of the criterion of the contract price (but not less than 20\%) when you place orders for the execution of research, development and engineering works (article 32, section 6) is regulated by law. However, for most other cases (including the purchase of existing innovative products) the ratio of the values of the significance of the criteria is not established by the Law on CS and in accordance with part 8 of article 32, it will be established by the regulatory legal act of the Russian Government.

We consider that the main disadvantage of the current Russian legislation on procurement is an excessive emphasis on price criteria in evaluation and comparison of bids, to the detriment of such criteria as functional and qualitative characteristics of products and the qualification of tenderers, which is totally unacceptable for procurement of innovative and scientific and technical products. 
In addition, the purchase of such products is often characterized by significant losses resulting from a possible default or improper performance of the concluded government contract (Shvets, S.K., 2011). Thus, the damage from spent public funds is not even such a very important aspect, as a loss of profit for the economy development (Yakovlev, P., 2013). The most common causes of improper performance of a public contract in the development of innovative products are called by researchers as a lack of qualifications and/or negligent contractors (Ivanova, V.O., 2012).

At the same time, the analysis of international experience allows us to conclude that the customer's task is not an independent calculation of the initial (maximum) contract price, but the analysis of the feasibility of price offers of potential contractors on the basis of the audit of the structure and scope of the planned costs during the placement of the R\&D orders and procurement of innovative products (with the assistance of independent experts, or in case of particularly expensive and complex orders the audit can be outsourced by professional audit companies). Thus, competitive negotiation procedures provided for by foreign laws allow the customer to optimize the cost of the order in case of detection of over-pricing in the potential contractor's offer (International experience in procurement reform: Lessons for Russia, 2012).

The study of foreign experience allows us to make a conclusion about inexpediency of the formal approach to the public order system, based solely on fiscal savings, and the need for applying a new approach to determining the goals and objectives of the state order system, according to which the state order is considered as one of the most important mechanisms of state regulation aimed at increasing the innovative activity of the population and business, modernization of the economy, improvement of public administration system.

\section{Conclusion}

In determining the prospects of development of legislation in this sphere it is necessary to consider new approaches to the implementation of the regulatory potential of the law. At first, the boundaries of legal regulation have been changed and the field of economic operators is increasingly expanding. First, the scope of legal regulation is changing and the field of economic agents gets more expanded. Secondly, the system of methods of actual legal regulation is becoming richer, value-targets, different ways of stimulation, technical and legal norms are more widely used. Third, more attention is paid to resource provision of the law and its economic feasibility. As a result of scientific and technological progress, new areas of relations, requiring complex legal regulation have emerged.

Currently, there is a need for a common conceptual approach to the creation of the national innovation system, as well as more uniform regulation of the innovation process. In this regard, it is necessary to improve both the law and law enforcement.

Many countries have enacted comprehensive laws on innovation. In Russia the question of the adoption of such law is raised, however, there arises the problem of availability of independent subject of legal regulation. The proposed law on innovation activity may relate to public law for the regulation of innovation activity, but it should not create administrative barriers.

The studies have shown that the formal procedures for placement of the orders provided for in the current legislation are constructed in such a way that the state customer creates his/her own technical specifications for R\&D implementation, evaluates the bids according to the criteria, where price and turnaround time are the main factors, and accepts the completion of the work, having no idea whether these results for the production of innovative products are necessary.

It is necessary to distinguish between procedures for placement of the order for the creation of innovative products, on the one hand, and the mechanisms to support fundamental and exploratory research, on the other hand.

\section{References}

The strategy of innovative development of the Russian Federation for the period up to 2020. Approved by the Decree of the Government of the Russian Federation as of December 08, 2011 No. 2227-r.

Federal Law "On the contract system in the procurement of goods, works and services for state and municipal needs" of 05.04.2013 No. 44-FZ. SZ RF. Date Views 08.04.2013.

DIRECTIVE 2014/24/EU OF THE EUROPEAN PARLIAMENT AND OF THE COUNCIL as of February 26, 2014

Nikonova, Y.I., 2013. Foreign experience of financial support of innovative development// Bulletin of Tomsk State University. Economy, $3(23)$.

Kazakov, V.V., 2012. Organizational and financial mechanism of the formation and implementation of innovation policy of economic systems. Bulletin of Tomsk State University, 363: 157-164.

Wessner, C., 2004. Innovation, Security, and Growth. Perspectives from the U.S. Innovation System. Myths, Realities, and 
Opportunities. Presentation at the 6 Countries Programme Workshop: Linking Defence and Security R\&D to Innovation: The Challenge Ahead, Brussels.

Smotritskaya, I.I. and S.I. Chernykh, 2012. From the state order to public procurement. Society and Economy, 9.

Afonasova, M.A. and E.A. Gantimurova, 2013. The state order for innovative products as a tool for enhancing innovation activities in the region. Bulletin of Tomsk State University. Economy, 2(17).

Peca, V., 2012. Demand driven innovation through public procurement. European Commission.

Prange, H., 2008. Explaining Varieties of Regional Innovation Policies in Europe. European Urban and Regional Studies, 15.

Appelt, S., 2013. Measuring public procurement of R\&D and innovation. Demand-driven innovation through public procurement: Precommercial Procurement and Public Procurement of Innovative Solutions, Berlin 21-22 March 2013.

Rubvalter, D.A. and S.S. Shuvalov, 2008. State Scientific and Technology Policy and the Federal contract system: international experience and its application in Russia. Economics of contemporary Russia, 1.

Fedorovich, V.A., A.P. Patron and V.P. Zavarukhin, 2010. Federal contract system: Mechanism of regulation of public management. Moscow: Science.

Smotritskaya, I.I. The state order as a mechanism to stimulate innovation activities of enterprises-residents of the special economic zone "Dubna". Date Views

http://www.hse.ru/mag/gz/2010--22/42582557.html.

Smotritskaya, I.I., 2014. Contract procurement system in the Russian economy: perspectives and limitations of development. Scientific report. Moscow: RAS Economy Institute.

Williamson, O.E., 2002. The Theory of the Firm as Governance Structure: From Choice to Contract. Journal of Economic Perspectives, 16(3).

Shvets, S.K., 2011. Scientific articles of Eurasian scientific forum "Science and education of modern Eurasia: traditions and innovations". Saint-Petersburg: MIEP.

Yakovlev, P., 2013. The state order is waiting for innovations. Bulletin of operational information "Moscow bids", 4: 8-9.

Ivanova, V.O., 2013. The concept of innovative products and features of their procurement. Economics: Yesterday, Today and Tomorrow, 5-6.

International experience in the reform of procurement system: Lessons for Russia, 2012. Moscow: SP RF. 